Андрос С. В.

канд. економ. наук., доцент ORCID ID: 0000-0001-5561-901X

Одеська нащіональна академія зв'язку імені О.С. Попова

\title{
БАНКІВСЬКЕ КРЕДИТУВАННЯ ІНВЕСТИЦИЙНИХ ПРОЕКТІВ У РЕАЛІЯХ ФІНАНСОВОГО РИНКУ
}

\section{БАНКОВСКОЕ КРЕДИТОВАНИЕ ИНВЕСТИЦИОННЫХ ПРОЕКТОВ В РЕАЛИЯХ ФИНАНСОВОГО РЫНКА}

\section{BANK LENDING OF INVESTMENT PROJECTS IN THE REALITIES FINANCIAL MARKET}

Розкрито особливості інвестииійної політики в різних економічних системах та встановлено взаємозалежність розвитку банків і суб'єктів господарювання. Проаналізовано сучасний стан інвестииійного прочесу в Україні та оцінено відповідність кредитування банками проектів потребам ринкової економіки. Сформульовані фактори впливу на ухвалення рімення інвестором про входження його в проект. Установлені причини $i$ фактори, щчо стримують розвиток банківського кредитування проектів в умовах фінансової глобалізації. Визначено основні напрями розвитку інвестиційного кредитування в мікроекономічному та макроекономічному аспектах. Обгрунтовано теоретичні та методологічні підходи до вирімення проблем банківського кредитування проектів в реаліях фінансового ринку. Установлено взаємозалежність економічних умов і участі банків у фінансуванні проектів. Опрацьовано механізм міжнародного інвестиційного фінансування та доведено необхідність активного залучення украӥнських банків в інвестииійний прочес. На основі аналізу довгострокової інвестиційної привабливості різних галузей промисловості, визначено напрями ефективного банківського кредитування проектів.

Ключові слова:банк, глобалізачія, економіка, інвестор, інвестииійний проект, кредитування, прибуток, проектне фінансування, ризик, фінансовий ринок.

Раскрыты особенности инвестиционной политики в различных экономических системах и установлена взаимозависимость развития банков и субъектов хозяйствования. Проанализировано современное состояние инвестиционного прочесса в Украине и оценень соответствие кредитования банками проектов потребностям рыночной экономики. Сформулированы факторы влияния на принятие решения инвестором о вхождении его в проект. Установлены причины и факторы, сдерживающие развитие банковского кредитования проектов в условиях финансовой глобализации. Определены основные направления развития инвестиционного кредитования в микроэкономическом и макроэкономическом аспектах. Обоснованы теоретические и методологические подходы к решению проблем банковского кредитования проектов в реалиях финансового рынка. Установлена взаимозависимость экономических условий и участия банков в финансировании проектов. Отработан механизм международного инвестиционного финансирования и доказана необходимость активного привлечения украинских банков в инвестиционный процесс. На основе анализа долгосрочной инвестищионной привлекательности различных отраслей промышленности, определены направления эффективного банковского кредитования проектов. 
Ключевье слова: банк, глобализация, экономика, инвестор, инвестиџионный проект, кредитование, прибыль, проектное финансирование, риск, финансовый рынок.

The article describes the features of the investment policies of various economies and established interdependence of banks and business entities. The current state of the investment process in Ukraine and assessed compliance project banks' lending needs of the market economy. The author formulated factors influence the decision to join its investor in the project. The established causes and factors that hinder the development of bank lending projects in the financial globalization. The main directions of investment lending to the micro and macro aspects. The author of theoretical and methodological approaches to solving the problems of bank lending projects in the realities of the financial market. Established the interdependence of economic conditions and the participation of banks in financing projects. The mechanisms for international investment funds and the necessity of active involvement of Ukrainian banks in the investment process. Based on the analysis of long-term investment attractiveness of various industries, the directions of effective bank lending projects.

Keywords: bank, globalization, economics, investor, investment project, credit, profit, project finance, risk, financial market.

Вступ. В Україні одним з головних джерел фінансування інвестиційних проектів $є$ банківське кредитування. Необхідність активізації участі банків в інвестиційному процесі випливає з взаємозалежності розвитку банківської системи та економіки. 3 одного боку, банки зацікавлені в стабільній економіці, що $\epsilon$ необхідною умовою їх успішної діяльності, з іншого, - стійкість розвитку підприємств істотно залежить від ступеня надійності банківської системи, іiі ефективного функціонування. Оскільки в глобалізованій економіці стратегії банків орієнтовані на отримання максимального прибутку при допустимому рівні ризику, участь банків у кредитуванні інвестиційних проектів відбувається лише за наявності сприятливих економічних умов.

Важливим завданням на етапі реформування вітчизняної банківської системи стає пошук шляхів підвищення ефективності діяльності українських банків в сфері інвестиційного кредитування. В даний час представлено багато вітчизняних i зарубіжних публікацій 3 окресленої проблематики. Широке коло проблем розглянуто в працях Воронцова В. В., Грицай Т. Л., Майорової Т. В., Пересади А. А. [1-4]. Ученими опрацьовано безліч підходів до розкриття такої категорії як «проектне кредитування»: кредитування, забезпечене економічною і технічною життєздатністю проекту, від реалізації якого очікується достатній притік фінансових ресурсів для обслуговування i виплати боргу, i де має місце прийнятний розподіл ризиків між його учасниками (Шенаєв В. Н.) [5]; фінансування окремої господарської одиниці, при якому кредитор готовий на початковому етапі розглядати фінансові потоки і доходи цієї господарської одиниці як джерело формування фондів, з яких буде здійснюватися погашення позики, і активи цієї господарської одиниці як додаткове забезпечення за позикою (Невітт П. К.) [6]; фінансування розробки або використання права, ресурсу чи іншого активу, при якому основна частина фінансування не буде надана за рахунок будь-якої форми акціонерного капіталу і буде повернута 3 доходів, 
вироблених цим проектом (Г. Д. Вінтер) [7]; банки фінансують конкретний проект i беруть на себе ризик успіху або невдачі цього проекту (Вуд П. Р.) [8].

Проте у вітчизняній літературі розглядаються в основному організаційні або процедурні питання кредитного процесу, надання короткострокових кредитів на поповнення оборотних коштів або експортно-імпортні операції. У зарубіжних джерелах наводиться банківська практика надання довгострокових позик у розвинутій економіці, що докорінно відрізняється від країн, що розвиваються, $\dot{i}$, відповідно, не може використовуватися без попереднього аналізу й адаптації міжнародних методик до українських умов. Зважаючи на це, наше дослідження спрямоване на вирішення проблеми банківського кредитування інвестиційних проектів у реаліях фінансового ринку.

Постановка завдання. Мета дослідження: розвинути теоретичні, методологічні та методичні положення покращення практики банківського кредитування інвестиційних проектів, використання яких дозволить підвищити ефективність кредитування українськими банками інвестиційних проектів в умовах реформування вітчизняної банківської системи.

Методологія. Методологічну основу науково-практичного дослідження формують діалектичний метод наукового пізнання, фундаментальні положення теорії фінансів та кредиту, наукові праці вітчизняних і зарубіжних учених у сфері банківського кредитування інвестиційних проектів.

Результати дослідження. Проблеми участі українських банків в інвестиційному процесі багато в чому пов'язані зі специфікою становлення української банківської системи. Протягом існування СРСР банки України у своїй діяльності не відчували ризику, оскільки банківська система, заснована на державній формі власності, працювала здебільше 3 державними підприємствами. Переважання державності в економіці означало, що за зобов'язаннями позичальників перед банками, у кінцевому рахунку, відповідала країна в особі міністерств і відомств. Необмежені платоспроможність і ліквідність країни в умовах неконвертованості національної валюти і закритої економіки захищали банки від ризиків, робили надмірною роботу банків з підтримки своєї ліквідності.

В результаті втрачалася практика виявлення, оцінки та моніторингу банківських ризиків у діяльності банків. Й. Шумпетер вважав, що в замкнутому господарстві чистий прибуток не існує, так як у ньому вартість всіх продуктів поширюється на засоби виробництва, а дохід виробників - лише плата за управління [9]. Крім того, особливості інвестиційної політики в закритих системах багато в чому пов'язано зі зменшенням обсягів виробництва, зокрема: споживач не впливає на інвестиційну політику; характерна інвестиційна напруженість (несумісність заявок на капіталовкладення і запланованих лімітів, затверджені інвестиційні програми не можуть бути здійснені відповідно до затвердженого кошторису i термінів, спостерігається розрив між потребами в інвестиціях i ресурсами); інвестиції відкладаються до тих пір, поки зростання граничних 
загальних витрат не досягне критичної величини, після здійснення інвестицій граничні загальні витрати падають, а після деякого часу все повторюється спочатку; інвестиції «розтягнуті» у строках; інвестиційна політика визначається державними органами, а не виробниками; капіталовкладення використовуються для розширення підприємства, сприяючи збільшенню випуску низькоякісної продукції; виробники звітують за суми освоєних капіталовкладень, а не за результати; велику частку займають невиробничі інвестиції; при вирішенні питання про інвестування не беруться до уваги чинники ефективності (близькість до джерел сировини, енергії, споживачів, якість робочої сили); екологічні фактори ігноруються; прерогативи при розподілі між банками кредитних ресурсів мають банки, які виконують функції агента уряду 3 фінансування і кредитування; підтримуються інвестиційні проекти (ІП) підприємств переважно для потреб країни [10].

В умовах ринкової економіки прерогатива інвестиційних кредитів у фінансуванні капітальних вкладень полягає у зворотності коштів, що зумовлює безпосередній зв'язок між фактичною окупністю здійснених витрат і поверненням позичок у визначені терміни. Це дозволяє кредитору протягом усього терміну кредитування здійснювати контроль за своєчасним освоєнням створених за рахунок кредиту виробничих потужностей і накопиченням коштів для погашення позик. Використання інвестиційного кредиту посилює матеріальну відповідальність підприємств за більш економне витрачання коштів, спрямованих на капітальні вкладення, дотримання встановлених термінів введення в дію основних фондів і прискорення окупності інвестицій. Одночасно підвищується зацікавленість банків-кредиторів у грунтовному аналізі внутрішніх резервів підприємств-позичальників, їх фінансовому становищі, можливостей щодо повернення кредитних ресурсів.

Кредитування в інвестиційній сфері, що передбачає перехід від безповоротного бюджетного фінансування до фінансування на платній і зворотній основі, пов'язане, перш за все, зі створенням ринкової інфраструктури в інвестиційній сфері й обмеженими можливостями бюджетного фінансування для відтворення основних фондів. У 1992 році в Україні помічалася тенденція істотного скорочення довгострокових кредитів через високий рівень процентних ставок, фінансову нестабільність, галопуючу інфляцію (10200\% на рік). Цей вид кредиту став недоступний державним підприємствам, особливо середнім i дрібним. До-речі, в Росії у 1991 році комерційні банки практично припинили кредитування довгострокових вкладень по всіх підприємствах [11].

Важливими умовами розвитку банківського кредитування капітальних вкладень у 1992 році в Україні були: реалізація заходів щодо вдосконалення системи розподілу ресурсів, зокрема встановлення економічно обгрунтованих оптимальних розмірів внутрішніх господарських ресурсів, що спрямовуються на цілі накопичення; чітке розмежування сфер бюджетного і кредитного способів 
надання коштів; організація кредитування на основі критеріїв жорсткого відбору ІП, ефективного використання виробничих ресурсів заявника на основі показників ефективності ІП; надання інвестиційних кредитів здійснювалося на конкурсних засадах у рамках цілей і завдань структурної перебудови економіки.

Інвестиційне кредитування проектів істотно відрізняється від звичайного кредиту за низкою чинників. По-перше, банк приймає на себе багато ризиків i отримує прибуток, пропорційний зростанню цін на продукцію підприємства, в яке здійснює вкладення. 3 цієї причини фінансовий стан позичальника оцінюється більш ретельно, розглядаються прогнози фінансистів стосовно майбутнього підприємства, темпи його розвитку і можливі доходи. По-друге, інвестиційне кредитування вимагає від позичальника певних вкладень, приблизно 20-50\% від необхідної для розвитку суми коштів. Якщо підприємство вже виконало частину плану за власні ресурси, це необхідно підтвердити документально. По-третє, якщо кредит на розвиток бізнесу, покупку нерухомості носить короткостроковий характер, то інвестиційне кредитування - це процес довгостроковий. Крім того, підприємствам, у проект яких банк інвестує кошти, надається можливість відстрочки сплати відсотків у разі тимчасових фінансових труднощів. Нарешті, якщо підприємству для подальшого розвитку ІП потрібний додатковий оборотний капітал, він може оформити його окремим кредитом або лінією кредитів [12].

Фактори, що мають принципове значення для інвестора при ухваленні рішення про входження в ІП, можуть стосуватися як фінансових аспектів, так і відображати стратегічні цілі інвестора. До фінансових факторів відносимо: оптимальний обсяг інвестицій; термін кредитування; прибутковість IП; зниження ризиків кредитора; високий ступінь контролю кредитора над IП; ділова репутація ініціатора ІП; участь в ІІ рекомендованих кредитором установ; якість маркетингової складової. Максимальні терміни кредитування ІП визначаються макроекономічною ситуацією і складають приблизно 5-7 років (СберБанк Росії). До речі, чим більше термін між початком ІП і надходженням від нього доходів, тим складніше залучити фінансування. Поріг мінімальної необхідної прибутковості інвестора визначається поточною ставкою рефінансування i розміром компенсованих проектних ризиків. Висока прибутковість ІП стимулює інвестора до прийняття більш високих значень ризиків. Потужні банки не розглядають IП, в яких вимога щодо зниження ризиків кредитора за рахунок участі ініціатора в ІП власними коштами не виконується. Ініціатор повинен вкласти в ІП близько $30 \%$ власних коштів від необхідного обсягу інвестицій.

Стратегічною метою проектного кредитування (проектного фінансування) $€$ фінансування IП, причому в якості забезпечення за проектним кредитуванням приймаються активи, які створюються у процесі реалізації IП, у тому числі майнові права на отримання активів у майбутньому. Позичальником і власником активів за ІП є компанія, спеціально створена під цей ІП. Особливостями такого 
виду банківського кредитування є тривалий термін співпраці і тісна залежність доходу кредитора від успішної реалізації ІП [13].

Найбільш активними лідерами українського ринку проектного фінансування у 2008 році були УкрексімБанк, Райффайзен Банк Аваль, Надра Банк, УкрсоцБанк, OPТ Bank, УкрСибБанк, Альфа-Банк, Правекс-Банк. Сьогодні, на жаль, відсутня офіційна статистика НБУ щодо обсягів проектного фінансування банками, наприклад, комерційної нерухомості. Банки не відкривають умов і не розголошують участь в ІП, що свідчить про незрілість даного сегменту ринку. Крім того, існує багато факторів, що стримують розвиток банківського фінансування проектів нерухомості: обмеження НБУ в обсягах інвестування; відсутність законодавчої основи для багатьох схем, що успішно працюють у світі (синдиковане кредитування і сек'юритизація); відсутність належної законодавчої процедури реалізації майнових прав на об'єкт нерухомості; складності прогнозування вартості ІП, пов'язані з ризиком зміни цін у цьому сегменті ринку.

В даний час консорціумне або синдиковане кредитування також не отримало широкого поширення на українському ринку. Серед причин, що перешкоджають розвитку синдикованого кредитування можна виділити: недостатньо розвинена нормативна база для синдикованих кредитів; переважна орієнтація українських банків на балансові показники при оцінці ризику; недостатня орієнтація на максимізацію прибутку за рахунок комісійних доходів порівняно з іноземними банками; недостатньо розвинений ризик-менеджмент для активного управління кредитними портфелями; нестача в банках фахівців з цього виду кредитування.

Консорціуми створюються для кредитування великих ІП, фінансування яких не під силу окремо взятим банкам. Об'єднання банків у консорціуми дозволяє банкам і їх клієнтам уникати жорстких обмежень НБУ на кредитування «в одні руки». Інсайдери при цьому отримують доступ до безлімітного фінансування. Примітно, що банківський консорціум не $є$ юридичною особою, а його учасники повинні тільки координувати свої дії в певній галузі - кредитуванні, депозитах, рекламі, але головне - банківський консорціум сам по собі не є об'єктом моніторингу з боку НБУ. Незважаючи на проблеми, що виникають у процесі створення консорціумів (можливий перехід клієнтів до банку-партнера; трудомісткість технології надання кредиту через домовленість про розподіл повноважень при виборі провідного банку або банку-координатора; громіздка процедура роботи банків-партнерів 3 клієнтом щодо переваг на видачу кредиту або стягнення предмету застави; забюрократизованість системи кредитування; розподіл ризиків неповернення кредиту між кредиторами), ситуативне об'єднання банків для подолання законодавчих і нормативних заборон неминуче [14].

У розрізі розглянутого, проблему проектного фінансування можна вирішити тільки з урахуванням конкретних обставин: в якій країні здійснюється IП; в якій економічній ситуації відбувається пошук фінансування IП; до якої галузі економіки відноситься ІП; на якій стадії розвитку перебуває IП; які переваги 
власників ІП щодо участі в ньому банків, що фінансують ІП; який масштаб ІП. Якщо йдеться про Україну, то це означає максимальний фінансовий ризик. Цей рівень спричинено такими чинниками, як фінансова нестабільність, війна, дефіцит державного бюджету. Теоретично це означає, що ІП в Україні для залучення фінансування повинен бути більш привабливий, порівняно зі звичайним ІП в іншій європейській країні. Натомість нестабільність фінансової системи України означає повну відсутність внутрішніх довгострокових дешевих ресурсів. Крім того, строк доступного банківського кредитування вимірюється місяцями, а типова потреба ІП у фінансуванні вимірюється роками, вже не йдеться про вартість кредиту в $20 \%$ і вище, яка передбачається до короткострокових грошей.

На сьогоднішній день спад попиту на інвестиційне кредитування в Україні пояснюється загальним зниженням інвестиційної активності, погіршенням якості кредитного портфеля банків, причому в ряді випадків девальвація гривні негативно вплинула на фінансування банками ІП. Серед факторів, що гальмують розвиток інвестиційного кредитування виділяємо:макроекономічні і інституційні. Ключовий фактор, що стримує фінансування банками ІП, - відсутність очікувань зростання економіки, а також зростаюча невизначеність, яка не дозволяє будувати прогноз на мінімальний термін для проектного фінансування. Причому це стосується як цінових прогнозів, так і стабільності регуляторного і податкового оточення, а також зниження рівня процентних ставок на тлі відсутності в економіці довгосрокових пасивів. Перевагу отримують галузі, що користуються механізмом державного субсидування процентних ставок. Серед основних макроекономічних проблем розвитку кредитування ІП в Україні можна назвати: тривалі терміни окупності IП, високе боргове навантаження, відсутність ліквідного забезпечення, високі кредитні ставки, високий рівень інфляції та волатильність гривні, які негативно впливають на ефективність ІП чи підвищують невизначеність у прогнозуванні майбутніх фінансових потоків. В умовах нестабільності самі клієнти менш охоче налаштовані на довгострокові інвестиції.

3 погіршенням кон'юнктури фінансових ринків ситуація в Україні ще більш погіршилася. Багато банків обмежили або закрили ліміти на фінансування ІП на невизначений термін. Поміняли свою стратегію в плані інвестування іноземні банки. Річ у тім, що основними кредиторами українських ІП виступали західні банки, які могли дозволити собі брати на баланс кредити, що видаються на проектне фінансування. Потім ці кредити сек'юритизувалися, що дозволяло банкам прибирати їх зі своїх балансів. Оскільки сек'юритизація призупинилася, то більшість банків призупинили видачу кредитів один одному. Це призвело до кризи ліквідності й обмежило можливість сек'юритизації. Банки змушені залишати кредити на своїх балансах. Зважаючи на вимоги до співвідношення кредитного портфеля і власного капіталу, така ситуація обмежує стратегічні можливості банків для видачі нових кредитів. Обсяг вільних для інвестування ресурсів у декілька разів зменшився. 
У процесі інвестиційного кредитування клієнтів, наприклад, ПріорБанк (Білорусь) може виступати не лише як прямий кредитор, а й організатор синдикованого кредиту (для реалізації великих ІП, які потребують залучення коштів декількох банків), а також як прямий лізингодавець або кредитор лізингової компанії, експерт бізнес-плану, консультант банку агента при організації зовнішнього фінансування, банк-гарант [15].

В Україні проект може розраховувати на особливу увагу банкірів, наприклад, з інформаційними технологіями. Це означає можливість пріоритетного доступу до спеціалізованих фінансових джерел некомерційного призначення. Якщо мова йде про стадію розвитку ІП, тут працює загальне правило: чим менш розвинений IП, тим менше шансів знайти для нього кошти. Український бізнес часто представляє ситуацію навпаки і свідомо занижує масштаби своїх ІП. Стосовно участі фінансистів в ІП, відмітимо, що власник ІП не завжди готовий залучити до бізнесу фінансиста на правах співвласника, оскільки в ньому він бачить тільки кредитора.

На практиці це означає усунення від фінансування більшої частини джерел, якими, є наприклад, інвестиційні фонди. Залучити ресурси для розробки нових технологій в Україні, на наш погляд, практично неможливо. Принаймні залучити кошти на розширення успішно функціонуючого бізнесу можна з імовірністю 90\%. Це відноситься, насамперед, до чистих технологій у тій же мірі, як до нових технологій в інших галузях. Так, Міжнародна фінансова корпорація (IFC) та УкргазБанк у 2016 році підписали угоду зі спрощення доступу до фінансування для компаній, які запроваджують відновлювальні та енергозберігаючі технології. IFC допоможе УкргазБанку наростити обсяги кредитування для малого i середнього бізнесу та корпоративних клієнтів у таких сферах, як енергоефективність, відновлювані джерела енергії, ефективне використання водних ресурсів та переробка відходів [16].

Спеціалізовані міжнародні фінансові інститути (МФI), які фінансують ІП в Україні, - це Свропейський банк реконструкції і розвитку(ЄБРР) і Міжнародні фінансові корпорації (МФК), а також Фонд чистих технологій, який, на відміну від ЄБРР і МФК, не має свого адміністративного апарату. Кошти Фонду чистих технологій можуть бути використані для фінансування ІП уповноваженими на це організаціями [в Україні такими є ЄБРР і МФК]. До-речі, МФІ негативно ставляться до великого українського бізнесу, в тому числі в сфері чистих технологій. Причина зрозуміла: МФІ фінансують великі ІП, але за умови прозорої репутації їхніх власників. Натомість корупційне походження більшої частини українських капіталів $€$ основним стримуючим фактором для звернення за фінансуванням до МФІ. На відміну від МФІ, МФК може профінансувати до 25\%, а ЄБРР до 35\% потреб ІП, решту коштів власники ІП повинні шукати з інших джерел. Крім того, ЄБРР і МФК виставляють жорсткі вимоги до співвідношення позикового і власного капіталу IП, яке на практиці означає, що до звернення до них за кредитом, потрібно мати власних коштів на суму не менше $30 \%$ вартості 
ІП. Хоча ставка по кредиту в цих організаціях становить 7-9\% річних, строк - не менше 5 років, але цих вимог достатньо, щоб зробити недоступним фінансування для більшості українських ІП. Складна і довга бюрократична процедура та високі вимоги до підготовки проектної документації властиве для всіх МФІ [17].

Необхідно зазначити, що для українського бізнесу пряме інвестування набагато дорожче кредитів МФІ. Використовувати цей інструмент потрібно, якщо кредитні ресурси недоступні або в недостатній кількості, або у випадку порушення допустимого співвідношення власного і позикового капіталу. Пряме інвестування можна отримати 3 двох принципово різних типів джерел - від промислових підприємств і від фінансових інвесторів. Інвестиції від промислових компаній дешеві, ніж від фінансових установ, проте промислові компанії дають інвестиції на умовах повного контролю над українським ІП, а фінансові компанії часто погоджуються на роль «молодшого» партнера. Крім того, поведінка фінансових інвесторів не залежить від галузевої специфіки. Стосовно ІП у сфері чистих технологій в Україні, фінансових інвесторів можна виокремити на двігрупи: інвестори, що спеціалізуються на технологіях; інвестори, що спеціалізуються на географічному регіоні (Україна, СНД, група країн Східної Європи) [18].

У процесі залучення грошей з інвестиційних фондів виникає низка проблем. Ідеться, передусім, про фінансову проблему: часто власники українського бізнесу мають вкрай завищене уявлення про ринкову вартість власного підприємства, що не дає можливості домовитися з інвестиційним фондом про частку в капіталі, що передається в обмін на інвестиції. Натомість місце розташування і термін інвестування у рази змінюють ринкову вартість бізнесу. Друга проблема пов'язана 3 виходом з ІП, що характерно для інвестиційних фондів. Фонд заробляє кошти, у першу чергу, не на прибутку підприємства, а на зростанні його ринкової вартості. Тому через 4-5 років після вкладення коштів він повинен їх повернути 3 прибутком, а для цього інвестиційний фонд повинен продати свою частку в бізнесі, як мінімум, у 2 рази дорожче, ніж вона йому дісталася. Для успішної співпраці інвестиційного фонду та власників підприємства потрібно 3 самого початку обумовити термін і умови виходу інвестиційного фонду 3 IП. Оптимальний спосіб для обох сторін - продаж частки через фондову біржу, але, на жаль, сьогодні він нереалістичний для українського бізнесу, тому часто застосовується продаж промисловому інвестору, а це вимагає узгоджених дій обох сторін.

Висновки. Проаналізовані особливості інвестиційної політики в закритій економіці та встановлено взаємозалежність розвитку банків і суб'єктів господарювання: клієнт не впливає на інвестиційну політику; характерна інвестиційна напруженість; інвестиції в ІП відкладаються до тих пір, поки зростання загальних граничних витрат не досягне критичної величини; інвестиції «розтягнуті» у термінах; політика визначається державними органами, а не 
виробниками; капіталовкладення використовуються для розширення підприємств, сприяючи збільшенню випуску низькоякісної продукції; виробники звітують за суми освоєних капіталовкладень, а не за фінансові результати; велику частку займають невиробничі інвестиції; у процесі інвестування ігноруються чинники ефективності, а також екологічні фактори; привілеї при розподілі між банками кредитних ресурсів мають банки, які виконують функції агента уряду 3 фінансування і кредитування; підтримуються ІП підприємств для потреб держави.

Сформульовані фактори впливу на ухвалення рішення інвестором про входження його в ІП: оптимальний обсяг інвестицій; термін кредитування; прибутковість ІП; зниження ризиків кредитора; високий ступінь контролю кредитора над IП; репутація ініціатора IП; участь в IП рекомендованих кредитором установ; якість маркетингу; масштаб бізнесу ініціатора; фінансовий стан; структура власності; активи; наявність досвіду роботи з іншими банками; професіоналізм управління; отримання прав на обслуговування рахунків клієнтів (елемент корпоративного фінансування).

Встановлені фактори, що стримують розвиток банківського кредитування IП в глобалізованій економіці: обмеження НБУ в обсягах інвестування; відсутність законодавчої основи для багатьох схем, що працюють у світі; відсутність належної законодавчої процедури реалізації майнових прав на споруджуваний об'єкт нерухомості; складності прогнозування вартості ІП, пов'язані з ризиком зміни цін на ринку та наростаючою невизначеністю в економіці; тривалі терміни окупності ІП; високе боргове навантаження; відсутність ліквідного забезпечення; високий рівень інфляції та волатильність гривні; погіршення якості кредитного портфеля, девальвація гривні; зниження рівня процентних ставок на тлі відсутності в економіці довгострокових дешевих пасивів.

Сформульовані причини, що стримують розвиток синдикованого кредитування в Україні: недостатньо розвинена нормативна база для синдикованих кредитів; переважна орієнтація українських банків на балансові показники при оцінці ризику; недостатня орієнтація на максимізацію прибутку за рахунок комісійних доходів порівняно з іноземними банками; нерозвинений ризик-менеджмент для активного управління кредитними портфелями; нестача в банках фахівців з цього виду кредитування.

Доведено, що основними цілями ситуативного об'єднання банків у консорціуми в реаліях фінансового ринку $\epsilon$ : кредитування великих IП, фінансування яких не під силу окремо взятим банкам; уникнення жорстких обмежень НБУ (інсайдери отримують доступ до безлімітного фінансування); мінімізації витрат; розширення ринків збуту; знаходження нових клієнтів; усунення сильних конкурентів; залучення додаткових інвестицій; оптимізації податків; збільшення прибутку та капіталізації; подолання законодавчих i нормативних заборон. 
Перспективи подальших наукових розробок пов'язані 3 нагальною необхідністю наукового аналізу й узагальнення кращого міжнародного досвіду в сфері банківського кредитування ІП. При цьому розроблені в розвинених країнах підходи щодо банківського кредитування ІП повинні бути критично переосмислені з урахуванням української економічної дійсності.

\section{Література:}

1. Воронцов В. В. Банковское кредитование инвестиционных проектов в промышленности [Электронный ресурс] : монография / Б. В. Воронцов, А. М. Колесников; ГУАП. - СПб. : 2007. - 132 c. - Режим доступа : http://window.edu.ru/resource/038/45038/files/kolecnikov.pdf

2. Грицай Т. Л. Інвестиційне кредитування, його сутність та значення в суспільних формах господарювання / Т. Л. Грицай // Інвестиції : практика та досвід. - 2011. - № 14. - С. 7-10.

3. Майорова Т. В. Інвестиційний процес і фінансово-кредитні важелі його активізації в Україні : монографія / Т. В. Майорова. - К. : КНЕУ, 2013. - 332 с.

4. Пересада А. А. Інвестиційне кредитування : навч. посібник / А. А. Пересада, Т. В. Майорова. К. : КНЕУ, 2002. $-271 \mathrm{c}$.

5. Шенаев В. Н. Проектное кредитование. Зарубежный опыт и возможности его использования в России / В. Н. Шенаев, Б. С. Ирниязов. - М. : Изд_во АО «Консалт_банкир», 1996. - 120 с.

6. Nevitt Peter K. Project Financing. Fifth edition. Published by Euro_money : London, 1989. - 405 p.

7. Vinter Graham D. Project Finance. A Legal Guide. London, Sweet \& Maxwell, 1995. - 151 p.

8. Wood Philip R. Project Finance, Subordinated Debt and State Loans. London, Sweet \& Maxwell (Law and Practice of International Finance), 1995. - 308 p.

9. Шумпетер Й. Теория экономического развития (Исследование предпринимательской прибыли, капитала, кредита, процента и цикла конъюнктуры) : пер. с англ. / Й. Шумпетер. М. : Прогресс, 1982. -455 с.

10.Ерохина Е. А. Теория экономического развития: системно-синергетический подход [Электронный ресурс] / Е. А. Ерохина. - Томск : Изд-во Томского ун-та, 1999. - 160 с. Режим доступа : http://ek-lit.narod.ru/eroh/3-2.html.

11.Еременко И. Кредитование инвестиционной сферы [Электронный ресурс] / И. Еременко, И. Николаева // ООО «РАУ-Университет», 1992. - № 25 (29). - Режим доступа : http://www.observer.materik.ru/observer/N25_93/25_10.HTM

12.0 порядке предоставления государственных кредитов на инвестиционные нужды предприятиям-инвесторам [Электронный ресурс]. - Министерство финансов Российской Федерации № 56 от 17.07.1992. - Режим доступа : https://www.lawmix.ru/prof/55697/.

13.Клепиков А. Кредитование инвестиционных проектов: формула успеха [Электронный pecypc] / А. Клепиков. - Режим доступа : http://www.old.rcb.ru/Archive/articles.asp?id=4785.

14.Вергелес В. Консорциумные кредиты [Электронный ресурс] / В. Вергелес, В. Погремушный // Газета «БИЗНЕС». http://www.uabanker.net/daily/2006/05/051006_0930.shtml.

15.Инвестиционные кредиты [Электронный ресурс]. - 2017. - Режим доступа : https://www.priorbank.by/investment-loans.

16.Укргазбанк буде кредитувати «зелені» проекти [Електронний ресурс]. - 2016. - Режим доступу : http://www.biowatt.com.ua/novosti/ukrgazbank-bude-kredituvati-zeleni-proekti/.

17.Новиков В. Мнение об инвестициях в проекты чистых технологий в Украине [Электронный pecypc] / В. Новиков. - 2010. - Режим доступа : http://www.energy-efficient.kiev.ua/node/5530. 
18.Соловей О. Проектное финансирование в реалиях украинского рынка [Электронный ресурс] / О. Соловей // Commercial Property. - 2008. - № 7 (59). - Режим доступа : http://commercialproperty.ua/analytics/top/detail.php?IBLOCK_ID=11\&ID=40132. 